\title{
AMPA Receptor Desensitization Predicts the Selective Vulnerability of Cerebellar Purkinje Cells to Excitotoxicity
}

\author{
James R. Brorson, ${ }^{1}$ Patricia A. Manzoliilo, Simon J. Gibbons, ${ }^{2, a}$ and Richard J. Miller ${ }^{2}$ \\ Departments of ${ }^{1}$ Neurology and ${ }^{2}$ Pharmacological and Physiological Sciences, The University of Chicago, Chicago, \\ Illinois 60637
}

Cerebellar Purkinje cells are selectively vulnerable to ischemia, although the reasons for this are unknown. In cultured embryonic rat cerebellar neurons, the steady state responses to the desensitizing agonist AMPA relative to responses to the nondesensitizing agonist kainate were greater in Purkinje cells compared to other cells, as measured by whole cell voltage clamp studies. Fluorimetric $\left[\mathrm{Ca}^{2+}\right]$, imaging experiments similarly found greater responses to AMPA relative to kainate in Purkinje cells than in other cerebellar neurons. In toxicity experiments measuring cell survival $24 \mathrm{hr}$ following agonist exposure, AMPA and glutamate produced $\mathrm{Ca}^{2+}$-dependent toxicity which was selective for the Purkinje cell fraction of the neurons, whereas kainate produced nonselective toxicity, and NMDA selectively spared the mature Purkinje cells. Cyclothiazide, which inhibits AMPA receptor desensitization, enhanced steady state current responses to AMPA and increased the toxicity of AMPA. We conclude that the vulnerability of cerebellar neurons in culture to glutamate agonist-induced toxicity parallels the magnitude of the steady state currents produced, and that Purkinje cells may be selectively vulnerable because they express AMPA receptors which undergo less complete desensitization.

IKey words: glutamate receptors, neurotoxicity, Purkinje cell, AMPA, kainate, NMDA, cyclothiazide]

Certain populations of neurons in the CNS are preferentially destroyed by a variety of toxic insults. In particular, among cerebellar neurons Purkinje cells are selectively vulnerable to global ischemia as well as to certain degenerative conditions. The reason for this selective vulnerability is not well understood. Excitotoxic damage due to glutamate receptor-mediated elevations in the intracellular free $\mathrm{Ca}^{2+}$ concentration $\left(\left[\mathrm{Ca}^{2+}\right]_{i}\right)$ is thought to be an important pathophysiological mechanism in neuronal death following ischemia (Choi, 1990). Some evidence also suggests that disruption of glutamate levels may occur in degenerative diseases of the cerebellum in which Purkinje cells are de-

\footnotetext{
Received Nov. 16, 1994; revised Jan. 20, 1995; accepted Jan. 24, 1995.

This work was supported by grant NS01630 from the NIH and a Schweppe Foundation Career Development Award to J.R.B., and by Grants DA-02121 and MH 40165 to R.J.M. S.J.G. was supported by a long-term fellowship from the Human Frontiers Science Program. We thank Dr. Doris Patneau for helpful comments on the manuscript.

Correspondence should be addressed to James R. Brorson, M.D., Department of Neurology, MC2030, The University of Chicago, 5841 South Maryland Avenue, Chicago, IL 60637.

aresent address: Department of GI Research, St. Elizabeth's Medical Center, Boston, MA

Copyright (C) 1995 Society for Neuroscience $0270-6474 / 95 / 154515-10 \$ 05.00 / 0$
}

stroyed (Plaitakis et al,, 1984). One postulated reason for differential tolerance to excessive glutamate receptor activation is that the mechanisms for buffering cytoplasmic $\mathrm{Ca}^{2+}$ differ from cell to cell. Indeed, the endogenous expression of high levels of the cytoplasmic $\mathrm{Ca}^{2+}$-binding protein calbindin $\mathrm{D}_{98 k}$ appears to confer resistance to excitotoxic death in hippocampal neurons (Scharfman and Schwartzkroin, 1989). However, Purkinje cells are alone among cerebellar neurons in expressing calbindin $D_{28 \mathrm{k}}$ (Sequier et al., 1990), having perhaps the highest calbindin $D_{28 k}$ content of any neuron in the brain, and yet they are the most sensitive cerebellar cell to ischemia. Another possible reason for selective vulnerability among neurons may relate to high expression of the NMDA receptor, which because of its high $\mathrm{Ca}^{2+}$ permeability is thought to be most important in mediating glutamate-induced excitotoxic death in many neurons. However, mature cerebellar Purkinje cells are uniquely lacking in expression of functional NMDA receptors (Audinat et al., 1990; Rosenmund et al., 1992). Thus, if glutamate mediates Purkinje cell death following ischemia, it must do so by activation of receptor classes other than the NMDA receptor.

Recently it has become clear that some non-NMDA receptors can also exhibit high $\mathrm{Ca}^{2+}$ permeability (Murphy and Miller, 1989; Iino et al., 1990; Hollmann et al., 1991). We have shown that in cultures of cerebellar neurons enriched in Purkinje cells, a number of the neurons express $\alpha$-amino-3-hydroxy-5-methyl4-isoxazole propionic acid (AMPA) receptors which, when activated by kainate, allow the direct entry of $\mathrm{Ca}^{2+}$ (Brorson et al., 1992). Furthermore, this $\mathrm{Ca}^{2+}$ permeation through AMPA receptors was sufficient to produce substantial delayed toxicity, and AMPA receptors werc more effective in mediating excitotoxicity than were NMDA receptors in the cerebellar neurons (Brorson et al., 1994). We postulated that a selective expression of $\mathrm{Ca}^{2+}$ permeable AMPA receptors by Purkinje cells might lead to a greater vulnerability to kainate toxicity. This did not prove to be true, since the percentage of calbindin $\mathrm{D}_{28 \mathrm{k}}$-staining neurons in the cultures did not change although over one-half of the cells died following kainate exposure. 'I'hus, the Purkinje cells were not more vulnerable to kainate than were the other neurons in these cultures. Based on the ontogeny of the rat cerebellum (Altman and Bayer, 1985a), these other cells are likely to be deep cerebellar nuclear neurons, basket cells, and stellate cells.

In pathological situations, the endogenous agonist acting on Purkinje neurons is most likely glutamate. Unlike kainate, glutamate acts upon AMPA receptors to evoke currents which rapidly desensitize to steady-state levels far smaller than the peak currents (Patneau and Mayer, 1991). In this sense, AMPA, which also causes desensitization, is more similar to glutamate in its 
actions upon AMPA receptors than is kainate. Previous work in cerebellar slices has suggested that unlike kainate, AMPA produces selective death of Purkinje cells by a delayed, $\mathrm{Ca}^{2+}-\mathrm{de}-$ pendent mechanism (Garthwaite and Garthwaite, 1991a; Garthwaite and Garthwaite, 1991b). In general, the maximal steady state currents evoked by glutamate or AMPA are small compared to those evoked by kainate. Yet we have previously noted that the relative size of the steady state current produced by AMPA varied widely when compared to that evoked by kainate. Here we investigate the relationship between the functional characteristics of the expressed AMPA receptors, in particular their desensitization properties, and the selective vulnerability of Purkinje cells to excitotoxicity mediated by these receptors.

\section{Materials and Methods}

Neuronal cultures. Cultures of cerebellar neurons from day 16 embryos were prepared largely as previously described in detail (Brorson et al., 1991), except that $15 \mathrm{mM}$ HEPES was added to the culture medium. Trypsin-dissociated neurons were plated on $15 \mathrm{~mm}$ round glass coverslips and suspended over a feeding glial layer in a serum-free defined medium (N2.1). These embryonic cerebellar cultures were shown to be enriched in Purkinje cells. In a similar manner, cultures of dissociated granule cells were prepared from postnatal day 8 rat pups, plated on coverslips at $3 \times 10^{5}$ cells $/ \mathrm{ml}$, and grown in $\mathrm{N} 2.1$ (containing $5 \mathrm{~mm}$ $\mathrm{KCl}$ ) over a feeding layer of glial cells. The granule cells survived well into the second week of culture without any additional factors.

Excitotoxicity assars. Cell death and survival were assayed using the fluorescent markers fluorescein diacetate and propidium iodide as previously described (Brorson et al., 1994). After 24 hr treatment with 10\% horse serum (GIBCO) to reduce background staining, the coverslips were then washed and exposed for $20 \mathrm{~min}$ at $37^{\circ} \mathrm{C}$ in room air to various agents in saline buffers to which tetrodotoxin $(0.5 \mu \mathrm{M})$ and bicuculline (20) $\mu \mathrm{M}$ ) were added to eliminate indirect synaptic contributions to toxicity. The usual saline buffer contained (in $\mathrm{mM}$ ) $\mathrm{NaCl} 145, \mathrm{KCl} 3, \mathrm{CaCl}$, 2. $\mathrm{MgCl}_{2}$, , HEPES 10, glucose 10 , pH to 7.4 with NaOH. For NMDA exposures the $\mathrm{MgCl}_{2}$ was omitted and $10 \mu \mathrm{M}$ glycine added. For $\mathrm{Ca}^{2}{ }^{2}$ free solutions, $\mathrm{CaCl}_{2}$ was omitted and $0.1 \mathrm{~mm}$ EGTA was added. After 20 min exposures, the coverslips were again washed, and returned to incubation in glia-conditioned, serum-free medium. One day later, the coverslips were washed in bufter, and then exposed for $4 \mathrm{~min}$ to fluorescein diacetate $(15 \mu \mathrm{g} / \mathrm{ml})$ and propidium iodide $(5 \mu \mathrm{g} / \mathrm{ml})$. The stained cells were examined on an epifluorescence microscope at wavelengths appropriate for each fluorophore. Living (fluorescein-stained) and dead (propidium jodide-stained) neurons were counted on adjacent fields of each coverslip to totals of at least 100 . by a blinded evaluator. The percentage of neurons surviving was determined on three coverslips for each condition in each experiment and this value was divided by that in parallel controls performed in the same ionic conditions to give the relative survival.

Cover slips treated in parallel were also immunostained for calbindin $\mathrm{D}_{2 \times k}$. using a monoclonal antibody (Sigma, St. Louis, MO) at a dilution of $1: 20,000$, as previously described (Brorson et al., 1991). Cells staining for calbindin $D_{2 \times k}$ and those negative for calbindin $D_{2 \times k}$ were counted to totals greater than 100 for each condition by a blinded evaluator. The specific survival of calbindin $D_{2 \times k}$-positive neurons for a given condition was calculated as the relative survival times the percent calbindin $D_{2 \times k}$ staining neurons in that condition, divided by the percent calbindin $\mathrm{D}_{2 \times \mathrm{k}}$ staining neurons in control-treated cells. The specific survivals of calbindin $\mathrm{D}_{2 \times h}$-negative neurons was calculated similarly, using percent calbindin $D_{2 \times h}$-negative neurons. These calculations assume that the agonist or control treatments do not change the calbindin $\mathrm{D}_{28 \mathrm{k}}$ staining properties of those neurons which survive. No qualitative change in the appearance of calbindin $\mathrm{D}_{2 \times \mathrm{h}}$ staining in surviving neurons was notable. The relative survival, the percent staining for calbindin $D_{2 \times k}$, and the specific survivals of calbindin $D_{2 \times h}$-positive and calbindin $D_{2 \times k}$-negative cells were determined in at least three separate experiments for each condition, and are expressed in the text and figures as the mean \pm SEM of these separate determinations. Differences between absolute survivals after treatments with various agonists and controls, between percentages of calbindin $\mathrm{D}_{2 \times 6}$-staining neurons, and between specific survivals of calbindin $D_{2 \times h}-p o s i t i v e$ and calbindin $D_{2 k h}$-negative neurons were compared using one-way repeated measures ANOVA followed by the Stu-
dent-Newman-Keuls method of pairwise comparisons (Sicimastat. Jandel Scientific).

Whole-cell patch clamping. Whole-cell patch-clamp measurements of ligand-gated $C a^{2+}$ currents were performed by two methods. For rapidapplication, borosilicate glass pipettes (World Precision Instruments. Inc.) of resistance 2-3 $\mathrm{M} \Omega$ were used without tip polishing. The whole cell capacitance was fully compensated and the series resistance compensated to approximately $50-80 \%$. Cells were accepted for study if a stable seal formed with a whole cell resistance of at least $100 \mathrm{M} \Omega$ and access resistance of less than $10 \mathrm{M} \Omega$. Cells were held at a membrane potential of $-80 \mathrm{mV}$ and agonists were applied by a rapid perfusion method as described by Tang et al. (1989). Briefly, a tapered theta-tube applicator was brought near to the cell and parallel solenoid valves (The Lee Company, Westbrook, CT) were controlled so as to switch off the control solution on one side of the theta-tubing simultaneously with the opening of agonist flow on the other side. Intracellular solutions contained (in mM) CsF 145, and BAPTA 10 . pH to 7.2 with $\mathrm{CsOH}$ (ATP was omitted to allow rundown of the voltage gated $C_{-} a^{2}$ currents). The extracellular saline buffer was as described above, with tetrodotoxin (TTX, $0.5 \mu \mathrm{M})$, and $\mathrm{Cd}^{2+}(100 \mu \mathrm{M})$ added to further eliminate synaptic and voltage gated currents. For NMD $\wedge$ applications, $\mathrm{Mg}^{2}$, and $\mathrm{Cd}^{2+}$ were omitted and glycine $(10 \mu \mathrm{M})$ added to the buffer. In addition, slow agonist applications using bath perfusion were utilized to measure ligatrd-gated $\mathrm{Ca}^{2+}$ currents, using a $\mathrm{Na}^{+}$-free extracellular buffer in which $N$-methyl-D-glucamine (NMDG) replaced all cations except $\mathrm{Ca}^{2+}$, and an intracellular solution containing NMDG fluoride and 10 mM BAPTA. as previously described (Brorson et al., 1992). All experiments were performed at room temperature. Data were recorded on a $\mathrm{PC}$-based system using an Axopatch $1 \mathrm{D}$ amplifier (Axon Instruments. Foster City, CA) and acquisition software based on $C-1 . A B$ II (Indec Systems Inc.. Sunnyvale, CA). For currents evoked by bath application. in which substantial rundown often occurred, AMPA currents were compared with the mean of flanking responses to kainate. Mean currents or current ratios in different cell types were compared using two-tailed Student's $t$ tests, and are reported in the text as mean \pm standard error of the mean

$1 \mathrm{Ca}^{2+} /$ imaging. Digital fluorescence microscopy was used to determine the correlation between the responses 10 agonisl-evoked rises in $\left[\mathrm{Ca}^{2+}\right]_{i}$ and immunocytochemica] staining for calbindin $\mathrm{D}_{2 \times \mathrm{k}}$. essentially as previously described (Holzwarth et al.. 1994). Cells were washed twice with the saline buffer described above and were loaded by incubation with fura- 2 acetoxymethyl ester (fura-2AM, $5 \mu \mathrm{M}$ ) for 30 min at $37^{\circ} \mathrm{C}$ in saline. Cells were then rinsed and incubated for a further 30 min at $37^{\circ} \mathrm{C}$ in a dye-free solution. Loading and completeness of deesterification were judged by stable fluorescence ratios and by ensuring adequate emitted fluorescence throughout the experiment for hoth 340 and $380 \mathrm{~nm}$ excitation wavelengths. Coverslips were mounted in a shallow chamber over an inverted stage fluorescence microscope (Nikon Diaphot) and continuously perfused with saline (flow rate $2.3 \mathrm{ml} / \mathrm{min}$ ). All drugs were dissolved and delivered in the perfusate. which also contained $0.5 \mu \mathrm{M}$ TTX. Cells were alternately illuminated with $340 / 380$ nm light from a Xenon source (Oriel) and emitted light wals passed through a $480 \mathrm{~nm}$ barrier filter into a Hamamatsu intensified CCD camera. Ratios of sequential $340 / 380 \mathrm{~nm}$ excitation image pairs were calculated and the fluorescence was converted to $\mid \mathrm{Ca}^{-}{ }^{-} \mathrm{I}$ using an acquisition system from Universal Imaging. Calibration curves were derived as previously described using shallow solutions of known $\mathrm{Cat}^{2+}$ and fura-2 concentration (Byron and Villereal, 1989). $\left[\mathrm{Ca}^{2+} l_{1}\right.$, values were collected approximately every $0.9 \mathrm{sec}$. so that the peak responses may have been slightly underestimated. For Na'-free solutions. Na' was replaced by equimolar $N$-methyl-D-glucamine and the $\mathrm{pH}$ adjusted with $\mathrm{HCl}$. $\mathrm{Mg}^{2+}$-free solutions were made by omitting the $\mathrm{MgCl}_{2}$ and adding $10 \mu \mathrm{M}$ glycine.

Materials. Cyclothiazide, the gift of the Lilly Company, was solubilized as a $10 \mathrm{~mm}$ stock in ethanol and stored at $4^{\circ} \mathrm{C}$. Propidium iodide was obtained from Aldrich Biochemicals (Milwaukee, WI). CNQX alld AMPA were purchased from Research Biochemicals, Inc. (Natick. MA). Other agents came from Sigma Chemical Co. (St. Louis, MO).

\section{Results}

\section{AMPA receptor desensitization in cerebellar nearons}

We studied the desensitization properties of AMPA receptors in cerebellar neurons in culture. Most of our observations describe phenotypically mature cultured neurons from embryonic day 16 


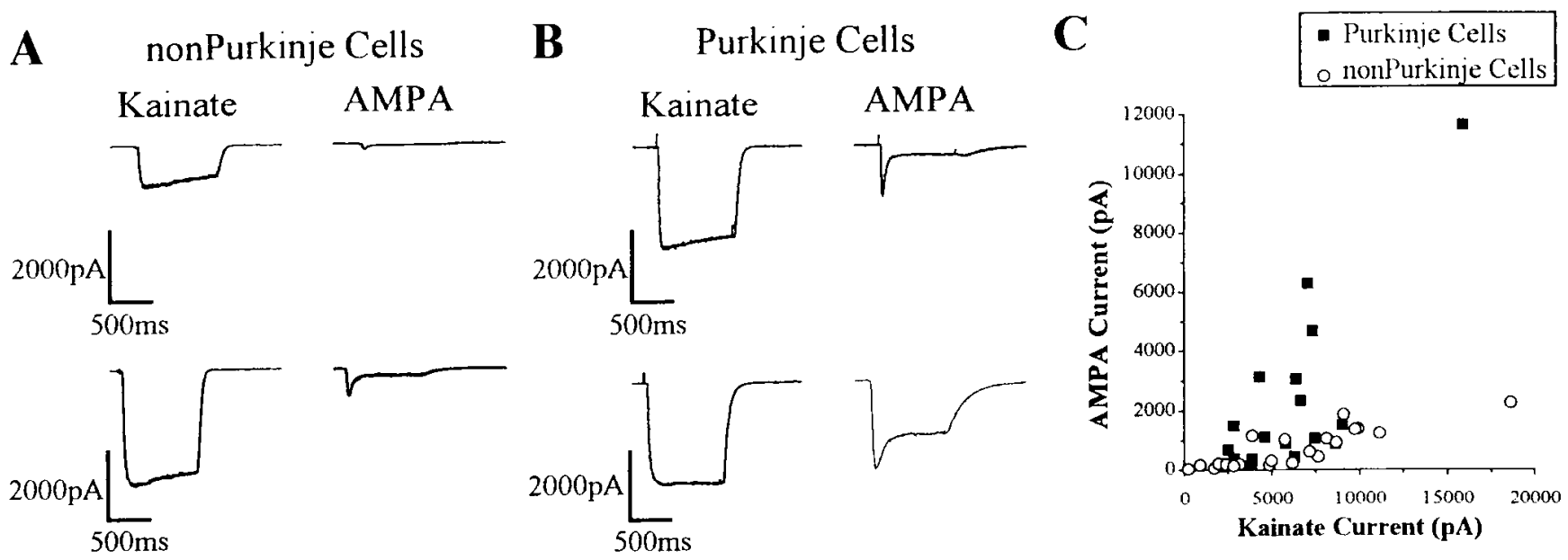

Figure 1. AMPA receptor currents in cerebellar neurons. Application of $100 \mu \mathrm{M}$ kainate and $30 \mu \mathrm{M}$ AMPA to whole-cell voltage-clamped cerebellar neurons, ages 14-28DIV, identified a priori by morphological criteria as non-Purkinje cells $(A)$ or as Purkinje cells $(B)$. Currents evoked by AMPA exhibited a rapidly desensitizing component, with kainate producing only slight or no desensitization. A number of cells with substantially less desensitization were found among the Purkinje cells. $C$, Scatter plot of the ratios of the steady state AMPA current to peak kainate current among the Purkinje cells (solid squares) and non-Purkinje cells (open circles).

rat cerebella. We have previously shown that in these cultures nearly one-half of the cells by the third week in vitro develop a recognizable morphology consisting of a large round soma with a single primary dendrite, and stain immunocytochemically for calbindin $\mathrm{D}_{2 x k}$, marking them as Purkinje cells (Brorson et al., 1991). The other cells in these cultures ("non-Purkinje cells") are putatively basket, stellate, and deep nuclear cerebellar neurons. Where explicitly stated, some observations were of postnatal cerebellar cultures, in which the large majority of neurons are granule cells.

A direct measurement of desensitization requires the comparison of peak to steady state current responses. In order to fully observe the peak responses of AMPA receptors to desensitizing agonists, fast application on the order of milliseconds is necessary (Tang et al., 1989; Patneau and Mayer, 1991). This speed is difficult to obtain in mature neurons with their extensive dendritic networks. However, the property most relevant to toxicity from prolonged exposures to agonist is likely to be the magnitude of the residual steady state current. In addition, the relative magnitude of the steady state current evoked by AMPA to that evoked by kainate, which produces relatively little desensitization, can be used as an indirect measure of the degree of desensitization (Jonas and Sakmann, 1992). We used an agonist application method as described by Tang et al. (1989), applied to whole-cell voltage-clamped neurons cultured from embryonic rat cerebella. Although we were unable to consistently measure the peak AMPA currents in the whole-cell mode, this method allowed a comparison of steady state currents evoked by various agonists. Effects of a saturating concentration of AMPA, $30 \mu \mathrm{M}$, were compared to those of $100 \mu \mathrm{M}$ kainate, a nonsaturating concentration chosen to avoid extreme whole cell current amplitudes.

In the cultures of embryonic cerebellar neurons, the ratio of the steady state current evoked by AMPA to the peak current evoked by kainate was quite variable from cell to cell (Fig. 1). Using morphological criteria to identify Purkinje cells a priori, we found in particular that this ratio varied greatly in the Purkinje cells, ranging from 0.04 to 0.89 , whereas in the non-Purkinje cells, the relative size of AMPA and kainate currents was less variable. The mean value of the ratio (steady state AMPA current divided by the peak kainate current) in morphologically identified Purkinje cells was $0.32 \pm 0.06(n=18$; mean \pm SEM), significantly greater than the mean ratio in the non-Purkinje cells, $0.10 \pm 0.01(n=22 ; p<0.001)$ (Fig. IC. Table 1). Thus, the Purkinje cells had larger steady state responses to AMPA relative to kainate than did the other cerebellar neurons in these cultures.

Because the use of morphological criteria to identify Purkinje cells might be unreliable, we also used a physiological property to classify the neurons. We, like others (Audinat et al., 1990); Rosenmund et al., 1992) have found that the mature cultured Purkinje cells are devoid of NMDA responses, unlike most other central neurons. In the voltage clamp experiments, a subset of the studied neurons were also tested for current responses to NMDA, and classified on this basis (Fig. 2). None of 11 morphologically identified Purkinje cells had any measurable currents evoked by NMDA, whereas 12 of 13 non-Purkinje cells expressed NMDA currents (magnitude $0.29 \pm 0.05$ relative to the $100 \mu \mathrm{m}$ kainate-evoked currents). Thus, this physiological parameter confirmed the general reliability of the morphological identification of Purkinje cells. Using only NMDA sensitivity as the criterion for identification, the NMDA nonresponders (presumed Purkinje cells) had a mean steady state $\Lambda M P \Lambda$-to-peak kainate current ratio of $0.34 \pm 0.09(n=12)$, while the NMDA responders had a mean ratio of $0.10 \pm 0.02(n=12, p=0.02)$. Thus, the results of classification by this physiological property corroborated the finding that Purkinje cells express greater steady state AMPA currents relative to the kainate currents.

Although we could not accurately measure the peak AMPA current to directly judge the degree of desensitization in the steady state currents, the relative size of the steady state AMPA current to the peak kainate current apparently reflected the degree of desensitization by AMPA. This was substantiated by the qualitatively different effects of combining AMPA with kainate. In the non-Purkinje cells, the addition of AMPA to kainate decreased the response compared to kainate alone, whereas in the Purkinje cells the addition of AMPA to kainate on average increased the steady state current response (Table 1), and always 
Table 1. Whole-cell capacitances, glutamate agonist-evoked currents, and current ratios (mean \pm SEM) in various cultured cerebellar cell types, identified morphologically

\begin{tabular}{|c|c|c|c|c|c|c|c|}
\hline Neuron type & $\begin{array}{l}\text { Age } \\
\text { (DIV) }\end{array}$ & $\begin{array}{l}\text { Capaci- } \\
\text { tance } \\
(\mathrm{pF})\end{array}$ & $\begin{array}{l}\mathrm{KA} \\
(\mathrm{pA})\end{array}$ & $\begin{array}{l}\text { AMPA } \\
\text { (pA) }\end{array}$ & $\begin{array}{l}\mathrm{KA}+\mathrm{AMPA} \\
(\mathrm{pA})\end{array}$ & $\begin{array}{l}\text { NMDA } \\
(\mathrm{pA})\end{array}$ & AMPA/KA \\
\hline Purkinje $(n=18)$ & $14-27$ & $56 \pm 5$ & $5986 \pm 767$ & $226 \pm 679$ & $7748 \pm 3296$ & $3 \pm 2$ & $0.32 \pm 0.06$ \\
\hline $\begin{array}{l}\text { Non-Purkinje } \\
\quad(n=22)\end{array}$ & $14-27$ & $28 \pm 3$ & $5977 \pm 915$ & $681 \pm 138$ & $4747 \pm 1901$ & $1934 \pm 479$ & $0.10 \pm 0.01 *$ \\
\hline $\begin{array}{l}\text { Immature cerebellar } \\
\qquad(n=8)\end{array}$ & 7 & $17 \pm 3$ & $769 \pm 138$ & $100 \pm 56$ & $396 \pm 148$ & $198 \pm 82$ & $0.13 \pm 0.05$ \\
\hline $\begin{array}{l}\text { Granule cell } \\
\quad(n=6)\end{array}$ & 12 & $5 \pm 1$ & $441 \pm 35$ & $27 \pm 5$ & $145 \pm 11$ & $139 \pm 24$ & $0.06 \pm 0.01^{*}$ \\
\hline $\begin{array}{c}\text { Nongranule } \\
(n-3)\end{array}$ & 1214 & $7 \pm 1$ & $2790 \pm 499$ & $533 \pm 132$ & $1915 \pm 352$ & $284 \pm 76$ & $0.19 \pm 0.02^{* *}$ \\
\hline
\end{tabular}

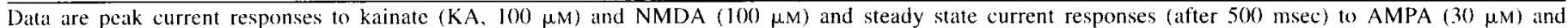
kainate+AMPA are reported.

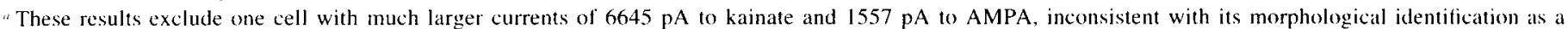
granule cell

* Significantly different from the AMPA/KA ratio in Purkinje cells (Student's $t$ test, $p<0.05$ ).

* Significantly different from the AMPA/KA ratio in granule cells (Student's $t$ test, $p<0.001$ ).

increased the measured peak response (Fig. 2). Overall, the ratio of the steady state current response to AMPA plus kainate divided by that to kainate alone correlated highly from cell to cell with the ratio of the steady state AMPA current to the kainate current $(R=0.92, p<0.001)$, suggesting that both ratios reflected the degree of desensitization of the same set of receptors.

Combinations of various high affinity kainate receptor subunits can also respond to AMPA and kainate (Herb et al., 1992). We found no evidence for responses mediated by these receptors. There were no observable rapidly desensitizing responses to $100 \mu \mathrm{M}$ or $10 \mu \mathrm{m}$ kainate (see Figs. 1, 2). The responses to AMPA exhibited high affinity, saturating at $10-30 \mu \mathrm{M}$ and were sensitive to block by CNQX at $20 \mu \mathrm{M}$ ( $n=6$, not shown). Furthermore, there was no measurable enhancement by concanavalin A $(0.3 \mathrm{mg} / \mathrm{ml}$ for $3 \mathrm{~min}, n=4)$, which preferentially modulates high affinity kainate receptors (Partin et al., 1993).

The morphological identification of Purkinje cells required working with mature cultured neurons of at least $14 \mathrm{~d}$ in vitro (DIV), and the measured kainate currents were quite large. In such cells, good voltage clamping of all the extended processes was almost certainly not achieved, and it might be that the differences between Purkinje cells and non Purkinje cells with respect to the ratios of AMPA current to kainate current was somehow a result of systematic space-clamping errors. This possibility was ruled out in scveral ways.

First, immature neurons (DIV 7), in which less complicated geometries and much smaller currents made for better space clamping, were also studied as to the relative magnitudes of AMPA versus kainate currents, and this ratio was again found to range widely from 0.02 to $0.47(n=8)$, in a manner not correlating with cell size as measured by whole cell capacitance (Fig. $2 C$ ). Thus this variation was expressed early in cultured life and was probably not merely due to voltage-clamp errors in larger neurons. Others have reported that Purkinje cells transiently express functional NMDA receptors during development (Krupa and Crepel, 1990; Rosenmund et al., 1992), and most of the immature neurons in our cultures, including putative developing Purkinje cells, expressed some NMDA-evoked current.

Second, we also made use of our previous observation that many of the neurons express $\mathrm{Ca}^{2+}$ currents carried by AMPA receptors, as measured in $\mathrm{Na}^{+}$-free solutions (Brorson et al. 1992). These currents are much smaller than the $\mathrm{Na}^{+}$currents induced by AMPA or kainate, and thus produce minimal voltage errors in the space clamp. For these studies, a slow bath superfusion method was used for agonist applications, so that there was no possibility of current contributions from capacitive compensation errors. Again using a priori morphological identification of Purkinje cells, we found that the $\mathrm{Ca}^{2+}$ currents evoked by $30 \mu \mathrm{M}$ AMPA relative to those evoked by $100 \mathrm{~mm}$ kainate were greater in the Purkinje cells $(0.31 \pm 0.08, n=11)$ versus the non-Purkinje cells $(0.12 \pm 0.03, n=21, p=0.01)$ (Fig. 3). As before, the effects of combining AMPA and kainate were often qualitatively different in Purkinje cells, where there was sometimes additivity of effects of AMPA and kainate, as compared to non-Purkinje cells, where the responses to AMPA plus kainate were decreased compared to kainate alone. The relative size of the current response to AMPA plus kainate compared to that of kainate alone again correlated with the ratio of the steady state AMPA current to the kainate current $(R=0.70, p<0.01)$.

Finally, we used $\left[\mathrm{Ca}^{2+}\right]$, imaging techniques to estimate responses to AMPA, kainate, and NMDA in the cerebellar neurons from the size of the peak rise in somatic $\left[\mathrm{Ca}^{2+}\right]$, which they induced. We followed the $\left[\mathrm{Ca}^{2+}\right]$, imaging experiments with immunocytochemical staining for calbindin $\mathrm{D}_{2 x k}$, to positively identify the Purkinje cells in the imaged fields. This method also showed that the calbindin $\mathrm{D}_{28 \mathrm{k}}$-positive Purkinje cells expressed a relatively greater response to AMPA with respect to the kainate response than did the non-Purkinje cells (Fig. 4). In calbindin $\mathrm{D}_{28 \mathrm{k}}$-positive neurons, the ratio of peak $\left[\mathrm{Ca}^{2}\right]_{i}$ values elicited by AMPA to those elicited by kainate was $0.52 \pm 0.08(n=24)$, while in calbindin $\mathrm{D}_{2 \times \mathrm{k}}$-negative neurons, this ratio was $0.38 \pm$ $0.05(n=76, p<0.05)$. Thus again a difference in relative responses to AMPA and kainate was indicated, in this case by a method not potentially hindered by the technical limitations of voltage clamping large neurons. Interestingly, the absolute magnitudes of all of the $\left[\mathrm{Ca}^{2+}\right]_{i}$ responses in the Purkinje cells were substantially smaller than those in the non-Purkinje cells, although in the voltage-clamp experiments, the current responses were found to be as large. This may be a reflection of the strong 


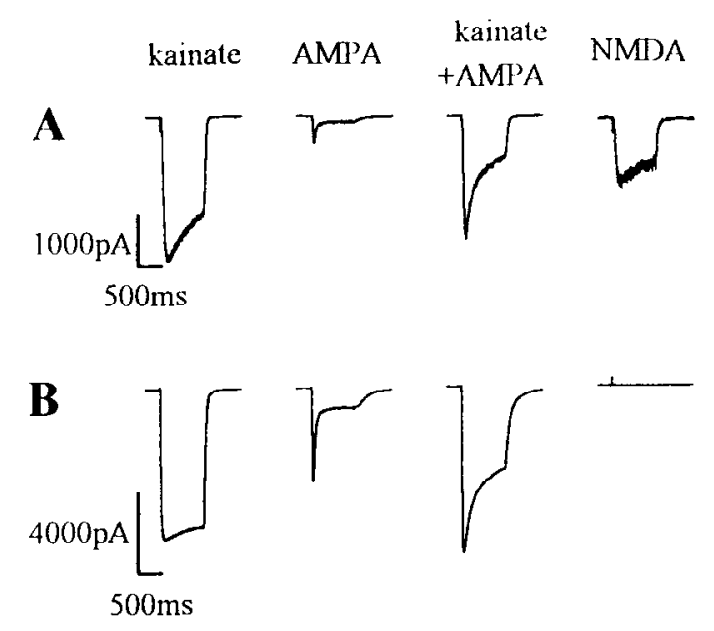

]$_{400 \mathrm{pA}}$
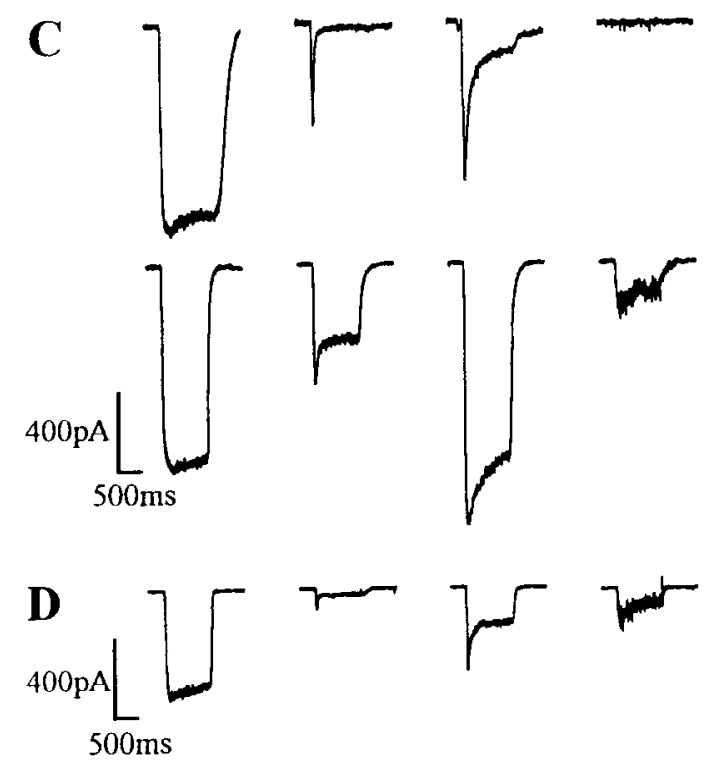

Figure 2. AMPA and NMDA receptor currents in cerebellar neurons. Application of $100 \mu \mathrm{M}$ kainate, $30 \mu \mathrm{M}$ AMPA, kainate plus AMPA, and $100 \mu \mathrm{M}$ NMDA to whole-cell voltage-clamped neurons. $A$, NonPurkinje neuron in mature culture (DIV20). $B$, Purkinje neuron in mature culture (DIV20). C, Immature cerebellar neurons, DIV7. Both cells were identified as possible immature Purkinje cells by morphology. $D$, Cultured cerebellar granule cell, DIV12.

buffering of entering $\mathrm{Ca}^{2+}$ by the high calbindin $\mathrm{D}_{28 \mathrm{k}}$ levels contained in the Purkinje cells (sce Discussion).

We also studied the effects of cyclothiazide (Fig. 3), a compound which blocks desensitization of AMPA receptors (Yamada and Tang, 1993). Cyclothiazide (10 $\mu \mathrm{M})$ increased the steady state currents in response to both $30 \mu \mathrm{M}$ AMPA and 100 $\mu \mathrm{M}$ kainate, by mean factors of $6.9 \pm 1.4$ and $1.7 \pm 0.1(n=$ 7); $100 \mu \mathrm{M}$ cyclothiazide had somewhat greater effects on the current responses to $100 \mu \mathrm{M}$ AMPA, enhancing them by a mean factor of $11.0 \pm 1.7$, and increased the currents evoked by 1000 $\mu \mathrm{M}$ kainate by $1.7 \pm 0.3(n=10)$. The AMPA currents were potentiated to the degree that in $100 \mu \mathrm{M}$ cyclothiazide the steady state AMPA currents were as large or larger than those evoked by kainate. These results are qualitatively consistent with those reported by Partin et al. $(1993,1994)$ and by Yamada and Tang (1993), although suggesting somewhat lesser degrees of current potentiation by cyclothiazide. Steady state AMPA and kainate
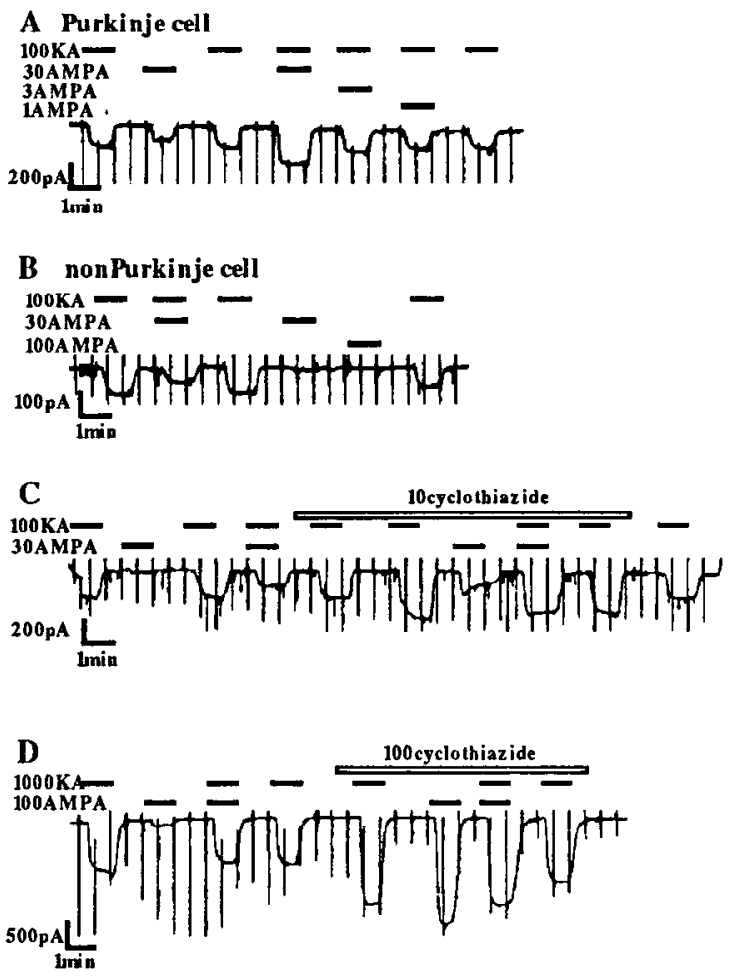

Figure 3. Ligand-gated $\mathrm{Ca}^{2+}$ currents in cerebellar neurons and the effects of cyclothiazide. All cations were replaced by the impermeant cation NMDG, save for the extracellular $\mathrm{Ca}^{2+}$, and recordings were performed in TTX $(0.5 \mu \mathrm{M})$ and $\mathrm{Cd}^{2+}(100 \mu \mathrm{M})$. Agonists were applied by bath superfusion at the holding potential of $-80 \mathrm{mV}$, while the cells were briefly depolarized to $0 \mathrm{mV}$ every $30 \mathrm{sec}$. The ligand-gated $\mathrm{Ca}^{2}$ " currents were recorded as changes in the whole cell current. $A$, Effects of kainate $(K A)$, AMPA, and combinations of kainate and AMPA in a Purkinje cell (DIV 21). B, Kainate and AMPA applied to a non-Purkinje cell (DIV 12). $C$, Effects of $10 \mu \mathrm{M}$ cyclothiazide on responses to 100 $\mu \mathrm{M}$ kainate and $30 \mu \mathrm{M}$ AMPA (non-Purkinje cell, DIV 14). D, Effects of $100 \mu \mathrm{M}$ cyclothiazide on responses to $1000 \mu \mathrm{M}$ kainate and $100 \mu \mathrm{M}$ AMPA (non-Purkinje cell, DIV 29).

currents were always potentiated by cyclothiazide. However, cells with highly desensitizing AMPA receptors had more desensitization persisting in the presence of cyclothiazide, in that the ratios of the AMPA current to the kainate current before and after potentiation by cyclothiazide were correlated. Also, cyclothiazide's potentiation of responses to AMPA plus kainate correlated with its effect on currents evoked by AMPA alone in a given cell. Cyclothiazide $(10 \mu \mathrm{M})$ had no effect on NMDA currents (not shown).

The most numerous cell of the cerebellum, the granule cell, is quite resistant to most toxicities which affect the cerebellum. Granule cells are not present in the cultures taken from embryonic day 16 rat cerebella, which have not yet developed an external granular layer (Altman and Bayer, 1985b). We were interested in also comparing the properties of cerebellar granule cells to those of the Purkinje cells with respect to glutamate receptor expression and toxicity. Cerebellar cultures prepared from postnatal day 8 rat cerebella consisted predominantly of small round cells, usually with bipolar processes-the typical morphology of cultured granule cells. A few cells were larger and triangular, suggesting that they were not granule cells but more likely basket or stellate cells. There were no cells with the morphology of Purkinje cells, and no cells stained for calbindin $\mathrm{D}_{28 \mathrm{k}}$ in these cultures. The nongranule cells present had large 
A

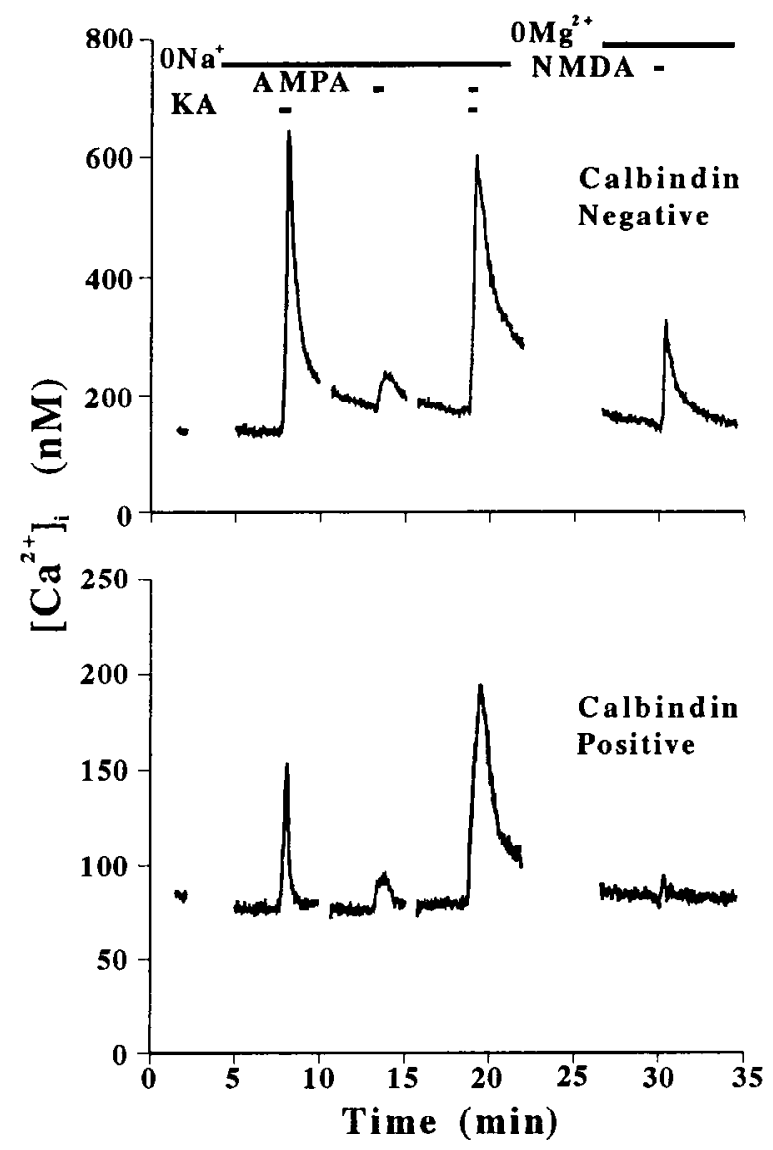

B

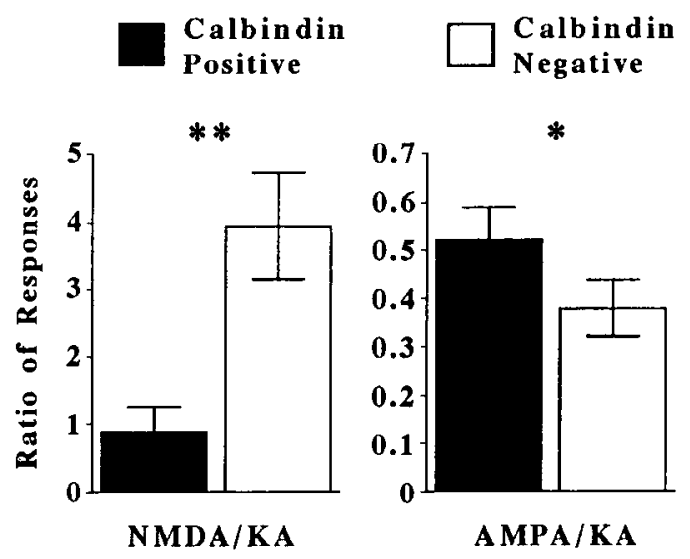

Figure 4. Fluorimetric $\left[\mathrm{Ca}^{2+}\right]$, imaging in immunocytochemically identified neurons. $A$, Traces of the $\left[\mathrm{Ca}^{2+}\right]$, versus time in two neurons (DIV 16) from the same microscopic field, subsequently identified immunocytochemically as a calbindin $\mathrm{D}_{2 \times \mathrm{k}}$-negative (upper trace) and a calbindin $\mathrm{D}_{2 \times \mathrm{k}}$-positive (lower trace) neuron. Absolute responses in $\mathrm{Na}^{-}$-free solution to $\triangle \mathrm{MPA}(30 \mu \mathrm{M})$, kainate $(K A, 100 \mu \mathrm{M})$, and NMDA $(100 \mu \mathrm{M})$ were substantially greater in the calbindin $D_{2 s k}$-negative neuron (note difference in scale), but the relative size of the response to AMPA conpared to that to kainate was greater in the calbindin $D_{28 \mathrm{~K}}{ }^{-}$ positive cell. $B$, Summary of average $( \pm$ SEM) peak responses to NMDA and to AMPA relative to kainate (same concentrations). Significant differences between calbindin $\mathrm{D}_{2 \times \mathrm{k}}$-positive and -negative cells are indicated $(*, p<0.05 ; * *, p<0.001)$.
AMPA and kainate currents, with current magnitudes and AMPA to kainate current ratios similar to the non-Purkinje cells in the embryonic cerebellar cultures (Table 1). In the typical granule cells, the absolute steady state current sizes were much smaller, being $27 \pm 5 \mathrm{pA}$ for $30 \mu \mathrm{M}$ AMPA $(n=6), 441 \pm$ $35 \mathrm{pA}$ for $100 \mu \mathrm{M}$ kainate $(n=7)$, and $139 \pm 24 \mathrm{pA}$ for 100 mM NMDA $(n=7)$ (Fig. $2 D)$. The average steady state AMPA to peak kainate current ratio was $0.06 \pm 0.01$, significantly less than that of the Purkinje cells. Thus, like other neurons of the cerebellum, granule cells differed from Purkinje cells in having much smaller ratios of the steady state AMPA current to peak kainate current, as well as displaying currents of lesser magnitude.

\section{Selective toxicity produced by glutamate receptor agonists}

We studied the delayed toxicity of glutamate agonists on Purkinje neurons in the embryonic cerebellar cultures by applying agonists for $20 \mathrm{~min}$ and assaying for survival relative to parallel controls after $24 \mathrm{hr}$. Most of the toxicity assays were performed on immature cultures (primarily DIV9), since the fraction of neurons surviving varied substantially after the second week in culture. Representative results in mature cultures are also described below. As we found in a previous study (Brorson et al.. 1994), $30 \mu \mathrm{M}$ AMPA was only moderately toxic to the cultured cerebellar neurons, reducing cell survival to $81 \pm 3 \%$ of controls $(n=4)$ (Fig. 5A). The combination of $30 \mu \mathrm{M}$ AMPA with $100 \mu \mathrm{M}$ kainate resulted in relative survival of $55 \pm 2 \%(n=$ 4). In separate experiments, $100 \mu \mathrm{M}$ kainate alone produced cell survival of $55 \pm 8 \%(n-3)$. To test whether the amount of toxicity was related to the desensitization produced by AMPA, we examined the effect of cyclothiazide on the delayed toxicity. Cyclothiazide (10 or $100 \mu \mathrm{M}$ ) produced a concentration-dependent potentiation of the toxicity of AMPA, with $100 \mu \mathrm{M} \mathrm{cy}$ clothiazide rendering AMPA at least as effective as $100 \mu \mathrm{M}$ kainate in producing overall toxicity. Thus the toxicity produced by $20 \mathrm{~min}$ exposures to various AMPA receptor agonists paralleled the relative magnitudes of the steady state currents which these agonists produced. The degree of toxicity seemed to relate inversely to the extent of receptor desensitization.

The toxicity of AMPA was $\mathrm{Ca}^{2+}$-dependent, as it could be largely blocked by removal of external $\mathrm{Ca}^{2+}$ during the $20 \mathrm{~min}$ exposure and for a $5 \mathrm{~min}$ period following AMPA exposure (Fig. $5 A$ ). This was also true for the toxicity of AMPA plus $10 \mu \mathrm{M}$ cyclothiazide (100 $\mathrm{M}$ cyclothiazide was not tested in $\mathrm{Ca}^{2+}$-free solution).

As we reported previously (Brorson et al., 1994), we again found that kainate was not selectively toxic to the Purkinje cells, as the percentage of surviving neurons staining for calbindin $\mathrm{D}_{2 \times k}$ was similar in kainate-treated cells $(41 \pm 6 \%)$ to parallel control cells $(41 \pm 7 \%, n=3$; note that Fig. $5 C$ displays only the control values for the AMPA experiments). In contrast to this nonselective toxicity produced by kainate, the toxicity of AMPA selectively decreased the percentage of cells staining for calbindin $\mathrm{D}_{2 \times k}$ (Fig. $5 B, C$ ). In cells treated in parallel with those used for toxicity assays, calbindin $\mathrm{D}_{2 \times k}$ staining revealed $44 \pm$ $9 \%$ calbindin $\mathrm{D}_{2 \times k}$-positive cells among those treated with control solutions, but only $30 \pm 7 \%$ among those treated with 30 $\mu \mathrm{M}$ AMPA. This fraction was further reduced, to $26 \pm 5 \%$ and $19 \pm 6 \%$, by $10 \mu \mathrm{M}$ and $100 \mu \mathrm{M}$ cyclothiazide, respectively. We calculated the specific survivals of the calbindin $D_{28 k}-$ positive and calbindin $D_{2 x k}$-ncgative populations of ncurons by comparing the overall survival and the percentage of stained cells 

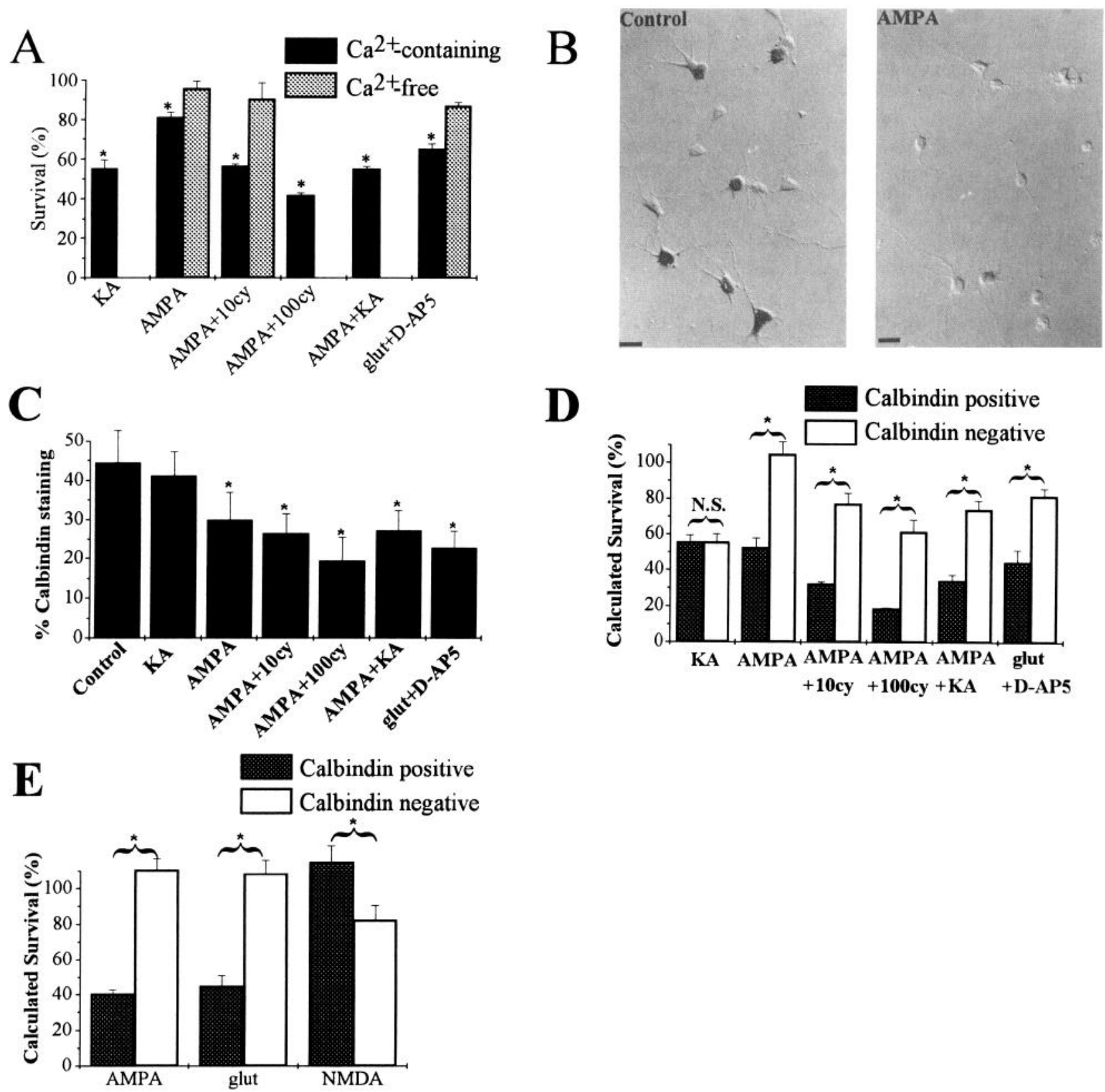

D

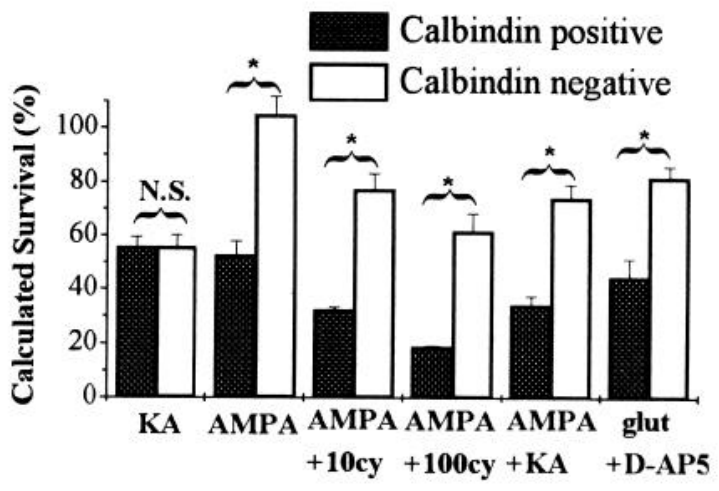

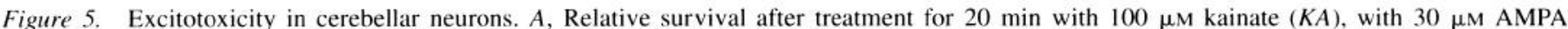

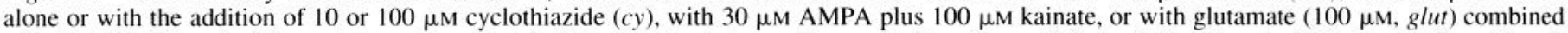

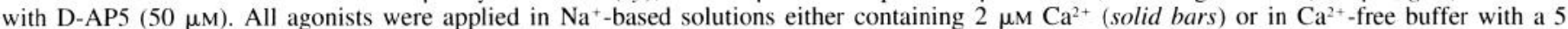

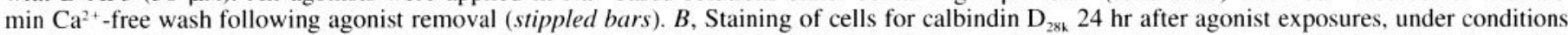

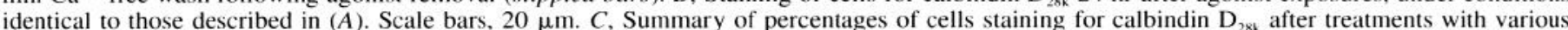

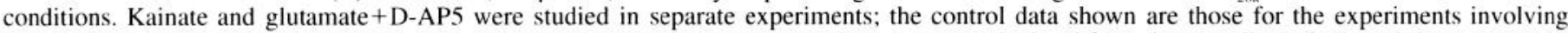

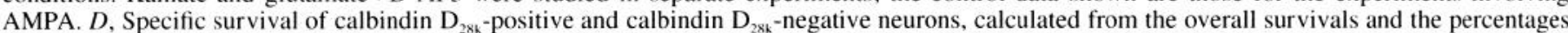

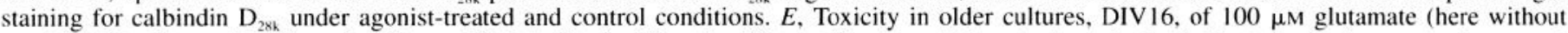

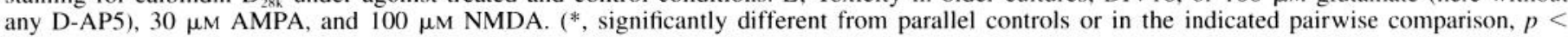
$0.05)$.

under each condition with the values for the control conditions (see Materials and Methods). These calculations revealed that the toxicity of AMPA was restricted to the calbindin $\mathrm{D}_{28 \mathrm{k}}$-positive cell fraction, representing the Purkinje cells (Fig. 5D). Enhancing the toxicity of AMPA with 10 or $100 \mu \mathrm{M}$ cyclothiazide or by the addition of $100 \mu \mathrm{M}$ kainate decreased the relative survival of both the calbindin $\mathrm{D}_{28 \mathrm{k}}$-positive and the calbindin $\mathrm{D}_{28 \mathrm{k}}$-negative populations, but the difference in survivals between these specific populations remained significant. Thus,
AMPA produced selective toxicity to the Purkinje cells relative to the other cerebellar neurons present in these cultures.

Glutamate is most likely the physiological agonist at the AMPA receptors in the cerebellum. We examined the effects of glutamate toxicity in a similar manner (Fig. $5 A, C, D$ ). In order to focus on the effects of glutamate upon AMPA receptors, it was applied in the presence of $50 \mu \mathrm{M}$ D-AP5, a selective antagonist of NMDA receptors. Under these conditions, glutamate produced a relative survival of $65 \pm 3 \%(n=4)$, and reduced 
calbindin $D_{2 \times k}$ staining in $23+4 \%$, compared to $37 \pm 9 \%$ in the parallel controls. Again, the calculated survivals of the calbindin $D_{2 k h}$-positive and of the calbindin $D_{2 \times k}$-negative fractions suggested that glutamate, like AMPA, was selectively toxic to the Purkinje cells. The toxicity of glutamate was partially blocked by removal of extracellular $\mathrm{Ca}^{2}{ }^{1}$, leaving $87 \pm 2 \%$ relative survival.

In the immature cerebellar cultures there was some expression of functional NMDA receptors by Purkinje cells (Rosenmund et al., 1992, and see above). Thus, $100 \mu \mathrm{M}$ NMDA, applied in the presence of $10 \mu \mathrm{M} C N Q X$ to eliminate indirect effects upon nonNMDA receptors, produced moderate toxicity, leaving $84 \pm 7 \%$ overall relative survival (not shown). However, unlike AMPA and glutamate, NMDA did not produce a significant difference in the specific survivals of the calbindin $D_{28 k}$-positive and the calbindin $D_{2 \times k}$-negative fractions, leaving relative survivals of 74 \pm 7 and $92 \pm 12 \%$. respectively $(n=3 ; p=0.27$, NS $)$.

We also examined toxicity in mature cultures of cerebellar Purkinje neurons at ages greater than 2 weeks in culture, by which time the morphological Purkinje cells had all lost any expression of NMDA receptors (see above). In these experiments, glutamate was applied without any NMDA antagonist, approximating the presumed pathophysiological situation of interest. As in the immature cells, AMPA and glutamate again produced moderate overall toxicity $(74 \pm 2 \%$ and $75 \pm 2 \%$ survivals, respectively; $n=4$ ), whereas the relative survival after NMDA treatment was insignificantly reduced to $93 \pm 6 \%$ $(n=4)$. The toxicity of AMPA and glutamate was again selective for the calbindin $D_{28 \mathrm{k}}$-positive cells, with calbindin $\mathrm{D}_{2 \times \mathrm{k}}$ staining reduced to $28 \pm 2 \%$ and $31 \pm 3 \%$ respectively, compared to $52 \pm 2 \%$ in the controls. In contrast, the calbindin $D_{2 \% k}$ staining after NMDA was actually somewhat increased compared to the $\mathrm{Mg}^{2+}$-free controls. Using these results to compute specific survivals of the calbindin $\mathrm{D}_{28 \mathrm{k}}$-positive and calbindin $\mathrm{D}_{2 \times h}$-negative neurons, there was a highly selective toxicity to the calbindin $\mathrm{D}_{2 \times \mathrm{k}}$-positive fraction induced by AMPA or glutamate. In contrast, NMDA instead produced a significant difference in the opposite direction, with specific toxicity to the calbindin $\mathrm{D}_{2 \times 3}$-negative fraction (Fig. $5 E$ ). Thus in the mature cultures the importance of AMPA receptors over NMDA receptors in the selective vulnerability of Purkinje cells was again clearly shown, and even the nonselective endogenous agonist, glutamate, produced selective Purkinje cell toxicity.

The vulnerabilities of Purkinje cells to glutamate agonist-induced toxicity contrasted sharply with the insensitivity to these agonists of granule cells in the postnatal cerebellar cultures. With similar 20 min exposures, neither $100 \mu \mathrm{M}$ kainate nor $30 \mu \mathrm{M}$ AMPA, nor AMPA plus $100 \mu \mathrm{M}$ cyclothiazide produced significant toxicity in postnatal cultured cerebellar neurons $(n=3$, not shown).

\section{Discussion}

Although there may be many different reasons for the patterns of selective neuronal vulncrability seen in various discase states, when neuronal death is mediated by excessive stimulation of glutamate receptors, the degree of prolonged activation of the relevant receptors would seem to be an important determinant. We have previously shown that cerebellar Purkinje neurons are relatively insensitive to toxicity induced by NMDA and quite sensitive to kainate toxicity (Brorson et al., 1994). Others have previously shown (Audinat et al., 1990; Rosemmund et al., 1992), and we also report here, that mature cerebellar Purkinje cells lack functional NMDA receptors, in contrast to their abundant expression of AMPA receptors. We further show that in contrast to other cerebellar neuronal types, Purkinje cells express AMPA receptors with a wide range of desensitization properties. Some cells express steady state AMPA currents with extensive desensitization compared to the (relatively) nondesensitizing currents evoked by kainate, while others express relatively large steady state AMPA currents. Because the degree of cross-desensitization by AMPA of kainate currents correlated closely with the relative size of the steady state currents evoked by AMPA alone, the relative magnitude of the steady state AMPA and kainate currents seems to relate to the desensitization of a common set of receptors.

A contribution from receptors such as those formed by GluR6 and KA-2, which respond to kainate with a rapidly desensitizing current but to high concentrations of AMPA with a steady state current (Herb et al., 1992), might possibly also account for a relatively large steady state current response to AMPA. Purkinje cells are known to express both GluR5 and KA-1, but reportedly not GluR6 nor KA-2 (Wisden and Seeburg, 1993). It is not known whether these subunits can produce a persistent AMPAevoked current. However, such responses, if similar to those resulting from other combinations of kainate receptor subunits, would be expected to respond only at high concentrations of AMPA and to be modulated by concanavalin A (Herb et al., 1992; Partin et al., 1993). In the present studies, there were no high affinity, rapidly desensitizing responses to kainate, although it may be that the agonist application speed was not adequate to observe such responses, which desensitize in milliseconds (Partin et al., 1993). The responses were evoked by AMPA and were blocked by CNQX at low concentrations, and they were strongly modulated by cyclothiazide but not by concanavalin $A$. Thus, the pharmacological properties suggest that AMPA receptors, rather than high affinity kainate receptors, contribute most of the observed current responses.

Other cerebellar neurons, including the mixed population of presumed deep nuclear, stellate, and basket cells cocultured with the Purkinje cells as well as granule cells cultured separately, were found to express AMPA receptors with a greater degree of desensitization by AMPA. The differences between the Purkinje cells and the cocultured non-Purkinje cells with respect to AMPA receptor desensitization were found whether the cell identification was based on morphology or on the physiological property of NMDA responsiveness. Furthermore, this difference was also found in mature neurons by patch-clamp measurements of the smaller whole cell currents in $\mathrm{Na}$-free solutions, and immature neurons with better voltage clamping properties also displayed a wide range of desensitization to AMPA. Finally, the result was confirmed by fluorimetric measurements of $\left[\mathrm{Ca}^{2+}\right]_{i}$ responses. Because of the saturating, nonlinear nature of the relationship between peak $\left[\mathrm{Ca}^{2+}\right]_{i}$ and the rate of $\mathrm{Ca}^{2}$ influx (Thayer and Miller, 1990; Bleakman et al., 1993), a simple linear correspondence between the relative magnitudes of $\left[\mathrm{Ca}^{2}{ }^{2}\right]_{i}$ peaks induced by AMPA and KA and the relative magnitudes of the whole cell currents they produced was not expected and was not found. Nevertheless, like the patch-clamp methods, $\left[\mathrm{Ca}^{2+}\right]_{i} \mathrm{mi}-$ crofluorimetric recordings showed a greater relative response to AMPA compared to kainate in Purkinje cells than in non-Purkinje cells.

These differences between the cultured Purkinje cells and the non-Purkinje cells suggested the hypothesis that Purkinje cells would be more susceptible to toxicity induced by prolonged ex- 
posures to desensitizing agonists of non-NMDA receptors. This was found to be the case, as the toxicity of AMPA or glutamate was confined to the calbindin $D_{28 \mathrm{k}}$-positive cell population either in immature cultures (primarily DIV9) or in more mature cultures (DIV16). In contrast, the nondesensitizing agonist kainate was equally toxic to either cell fraction. In the mature cultures, NMDA produced selective toxicity to the non-Purkinje cell fraction, whereas glutamate exhibited substantial toxicity which was confined to the Purkinje cell fraction. This confirmed that the physiological agonist was acting not on NMDA receptors but primarily on AMPA receptors when it induced selective toxicity to the Purkinje cells. It is also possible that part of the toxic action of glutamate might take place through activation of metabotropic receptors, which are prominently expressed in Purkinje cells (Yuzaki and Mikoshiba, 1992). This could account for the incomplete block of glutamate toxicity by removal of extracellular $\mathrm{Ca}^{2+}$.

The selective toxicity of AMPA to Purkinje cells cannot be explained merely by a larger number of non-NMDA receptors or by a greater density of receptors, since the currents activated by kainate were no greater than in the non-Purkinje cells, although the Purkinje cells were larger in surface area as judged by the average whole cell capacitance (Table 1). Interestingly, the increased toxicity of AMPA to the calbindin $\mathrm{D}_{28 \mathrm{k}}$-containing cells occurred despite the fact that the Purkinje cells had a lower peak $\left[\mathrm{Ca}^{2+}\right]_{i}$ in response to brief applications of AMPA (Fig. 4), presumably as a result of the strong buffering of incoming $\mathrm{Ca}^{2+}$ by the high concentration of calbindin $D_{28 \mathrm{k}}$. This result runs counter to studies of hippocampal cells which have shown resistance to glutamate toxicity in the calbindin $\mathrm{D}_{28 \mathrm{k}}$-containing neurons (Scharfman and Schwartzkroin, 1989). However, as Dubinsky (1993) has shown, the neuronal $\mathrm{Ca}^{2+}$ buffering capacity may be overwhelmed over long periods of exposure to glutamate agonists. The continued rate of ion influx is likely to determine toxicity, despite cytoplasmic buffering.

Inhibition of desensitization by cyclothiazide and cross desensitization of kainate responses by AMPA were used to manipulate the degree of AMPA receptor desensitization in the toxicity experiments. Cyclothiazide at $10 \mu \mathrm{M}$ substantially enhanced AMPA toxicity, and at $100 \mu \mathrm{M}$ rendered it at least as great as the toxicity of kainate. The toxicity to both calbindinpositive and to calbindin-negative neurons was increased by cyclothiazide, paralleling its enhancing effects on whole cell currents evoked by AMPA in both cell types. The addition of AMPA to kainate increased the specific toxicity to Purkinje cells but decreased that to non-Purkinje cells relative to kainate alone (Fig. 5D). This paralleled the different effects on steady state membrane currents of adding AMPA to kainate in Purkinje cells and non-Purkinje cells (Table 1). Thus the toxicity induced by various agents correlated with the steady state membrane currents which they evoked in various cell types. We infer that the amount of toxicity related to the degree of desensitization of AMPA receptors, and that the specific toxicity of AMPA and glutamate to the Purkinje cell population most likely was a result of the lesser degrees of desensitization of the AMPA receptors which these cells expressed.

Others have shown that the toxicity mediated by activation of AMPA receptors can be modulated by agents that reduce receptor desensitization. Zorumski et al. (1990) showed that in cultured hippocampal neurons, both the steady state current and the acute neuronal degeneration evoked by quisqualate were increased by the lectin wheat germ agglutinin. May et al. (1993) showed that $10 \mu \mathrm{M}$ cyclothiazide also enhanced toxicity in hippocampal cultures when exposed to AMPA or kainate. Moudy et al. (1994) found that cyclothiazide increased the toxicity of glutamate in cultured hippocampal neurons. However, the results presented here now link differences in desensitization of expressed AMPA receptors anong various neuronal types to selective vulnerability to toxicity.

The structural basis for the resistance of Purkinje cells to receptor desensitization is likely to relate to differences in receptor subunit composition resulting from the pattern of expression of the various flip and flop splice variants of the AMPA subunits, since different combinations of these subunits have been shown to exhibit quite different desensitization properties (Sommer et al., 1990). Coexpression of the flop splice variants of GluR1 and GluR2 in mammalian cells resulted in highly desensitizing AMPA receptors, with steady state glutamate current to peak kainate current ratios of approximately 0.1 (using $300 \mu \mathrm{M}$ glutamate, $300 \mu \mathrm{M}$ kainate), while a combination of the pure flip forms of GluR1 and 2 produced a ratio of approximately 0.7 (Sommer et al., 1990). Mixtures of flip and flop splice variants of GluR1 and GluR2 produced intermediate ratios, with an apparently greater influence of GluR2 on desensitization properties (Sommer et al., 1990; Partin et al., 1994). The splice variant forms of GluR3 and GluR4 were reported to have an even stronger influence on the desensitization properties of the AMPA receptors formed from homomeric and heteromeric combinations with GluR2 (Mosbacher et al., 1994). Purkinje cells have been reported to express both splice variants of GluR1 and GluR2, but primarily the flip form of GluR3 with little GluR3 flop expressed (Sommer et al., 1990; Lambolez et al., 1992). In PCRbased assays of AMPA receptor subunit expression, we have found the suggestion of a similar pattern of expression in the cultured Purkinje cells (P. A. Manzolillo and I. R. Brorson, unpublished results). Although this pattern of mRNA expression must be confirmed as representing the pattern of expression at the level of functional receptors as well, the AMPA subunit expression pattern of Purkinje cells, and in particular the difference in expression of the flip versus flop forms of GluR3, may account for the resistance to desensitization of AMPA receptors in Purkinje cells. The effects of cyclothiazide in our current measurements, in which the cells with more highly desensitizing AMPA receptors continued to show more persisting desensitization even in the presence of cyclothiazide, may also be explained by the subunit expression pattern. In receptors formed from various combinations of GluR1 and GluR2, Partin et al. (1994) found that while $100 \mu \mathrm{M}$ cyclothiazide potentiated the steady state responses to glutamate of all combinations of subunit splice variants, there remained some desensitization, particularly in the combination of flop forms. As a result, one might expect potentiation of toxicity by cyclothiazide in both cells with greater and cells with lesser degrees of AMPA receptor desensitization, but possibly a persisting difference in toxicity based on some desensitization occurring despite cyclothiazide. Thus, cyclothiazide increased the specific toxicity of AMPA in both Purkinje cells and non-Purkinje cells, maintaining the selectively greater toxicity in the Purkinje cell fraction (Fig. 5D).

Resistance to desensitization of glutamate receptors may contribute to selective vulnerability in other neurons as well. CA3 and CA1 hippocampal pyramidal neurons have been shown to differ in the degree of desensitization of their AMPA receptors (Jonas and Sakmann, 1992), and CA3 neurons are more vulnerable to AMPA toxicity than are CA1 neurons (Garthwaite and 
Garthwaite, 1991a). Motor neurons in spinal cord slice culture have been found to be selectively vulnerable to toxicity mediated by non-NMDA receptors (Rothstein et al., 1993), and motor neurons preferentially express the flip forms of GluR2 and GluR4 subunits, while expressing both flip and flop forms of GluR3 (Tölle et al., 1993). It is possible that selective death of motor neurons relates to these differences of AMPA receptor subunit expression. Such mechanisms may be widely relevant to patterns of selective vulnerability in the CNS, wherever longterm exposure to glutamate and non-NMDA receptors are involved.

\section{References}

Altman J, Bayer SA (1985a) Embryonic development of the rat cerebellum. I. Delineation of the cerebellar primordiun and early cell movements. J Comp Neurol 231:1-26.

Altman J, Bayer SA (1985b) Embryonic development of the rat cerebellum. II. Translocation and regional distribution of the deep neurons. J Comp Neurol 231:27-41.

Audinat E, Knopfel T, Gahwiler BH (1990) Responses to excitatory amino acids of Purkinje cells and neurones of the deep nuclei in cerebellar slice cultures. J Physiol (Lond) 430:297-313.

Bleakman D, Roback JD, Wainer BH, Miller RJ, Harrison NL (1993) Calcium homeostasis in rat septal neurons in tissue culture. Brain Res 600:257-267

Brorson JR, Blcakman D, Gibbons SJ, Miller RJ (1991) The properties of intracellular calcium stores in cultured rat cerebellar neurons. J Neurosci 11:4024-4043.

Brorson JR, Bleakman D, Chard PS, Miller RJ (1992) Calcium directly permeates kainate/ $\alpha$-amino-3-hydroxy-5-methyl-4-isoxazolepropionic acid receptors in cultured cerebellar Purkinje neurons. Mol Pharmacol 41:603-608

Brorson JR, Manzolillo PA, Miller RJ (1994) $\mathrm{Ca}^{2+}$ entry via AMPA/ KA receptors and excitotoxicity in cultured cerebellar Purkinje cells. J Neurosci 14:187-197.

Byron K, Villereal M (1989) Mitogen induced changes in individual human fibroblasts. I Biol Chem 264:18234-18239.

Choi DW (1990) Cerebral hypoxia: some new approaches and unan swered questions. J Neurosci 10:2493-2501.

Dubinsky J (1993) Effects of calcium chelators on intracellular calcium and excitotoxicity. Neurosci Lett 13:623-631.

Garthwaite G, Garthwaite J (1991a) AMPA neurotoxicity in rat cerebellar and hippocampal slices: histological evidence for three mechanisms. Eur J Neurosci 3:715-728.

Garthwaite G, Garthwaite J (199/b) Mechanisms of AMPA neurotoxicity in rat brain slices. Eur J Neurosci 3:729-/36.

Herb A, Burnashev N, Werner P, Sakmann B, Wisden W, Seeburg PH (1992) The KA-2 subunit of excitatory amino acid receptors shows widespread expression in brain and forms ion channels with distantly related subunits. Neuron 8:775-785.

Hollmann M, Hartley $\mathrm{M}$, Heinemann $S$ (1991) $\mathrm{Ca}^{2+}$ permeability of KA-AMPA-gated glutamate receptor channels depends on subunit composition. Science 252:851-853.

Holzwarth JA, Gibbons SJ, Brorson JR, Philipson LH, Miller RJ (1994) Glutamate receptor agonists stimulate diverse calcium responses in different types of cultured rat cortical glial cells. J Neurosci 14:18791891

Iino M, Ozawa S, Tsuzuki K (1990) Permeation of calcium through excitatory amino acid receptor channels in cultured rat hippocampal neurones. J Physiol (Lond) 424:151-165.

Jonas P, Sakmann B (1992) Glutamate receptor channels in isolated patches from $\mathrm{CA} 1$ and $\mathrm{CA} 3$ pyramidal cells of rat hippocampal slices. J Physiol (Lond) 455:143-171.
Krupa M. Crepel F (1990) Transient sensitivity of rat cerebellar Purkinje cells to $N$-methyl-D-aspartate during development: a voltage clamp study in in vitro slices. Eur J Neurosci 2:312-316.

Lambolez B, Audinat E, Bochet P, Crépel F, Rossier J (1992) AMPA receptor subunits expressed by single Purkinje cells. Neuron 9:247258.

May PC, Robison PM (1993) Cyclothiazide treatment unmasks AMPA excitotoxicity in rat primary hippocampal cultures. J Neurochem 60: $1171-1174$

Mosbacher J, Schoepfer R, Monyer H, Burnashev N, Seeburg PH, Ruppersberg JP (1994) A molecular determinant for submillisecond desensitization in glutamate receptors. Science 266:1059-1062.

Moudy AM, Yamada KA, Rothman SM (1994) Rapid desensitization determines the pharmacology of glutamate neurotoxicity. Neuropharmacology 33:953-962.

Murphy SN, Miller RJ (1989) Regulation of $\mathrm{Ca}^{+4}$ influx into striatal neurons by kainic acid. J Pharmacol Exp Ther 249:184-193.

Partin KM, Patneau DK, Winters CA, Mayer ML, Buonanno A (1993) Selective modulation of desensitization at AMPA versus kainitle receptors by cyclothiazide and concanavalin A. Neuron 11:1069-1082.

Partin KM, Patneau DK, Mayer ML (1994) Cyclothiazide differentially modulates desensitization of $\alpha$-amino-3-hydroxy-5-methyl-4-isoxiazolepropionic acid receptor splice variants. Mol Pharmacol 46:129138

Patneau DK, Mayer ML (199I) Kinetic analysis of interactions between kainate and AMPA: evidence for activation of a single receptor in mouse hippocampal neurons. Neuron 6:785-798.

Plaitakis A, Berl S, Yahr MD (1984) Neurological disorders associated with deficiency of glutamate dehydrogenase. Ann Neurol 15:144 153

Rosenmund C, Legendre P. Westbrook G (1992) Expression of NMDA channels on cerebellar Purkinje cells acutely dissociated from newborn rats. J Neurophysiol 68:1901-1905.

Rothstein JD, Jin L, Dykes-Hoberg M. Kuncl RW (1993) Chronic inhibition of glutamate uptake produces a model of slow neurotoxicity. Proc Natl Acad Sci USA 90:6591-6595.

Scharfman HE, Schwartzkroin PA (1989) Protection of dentate hilar cells from prolonged stimulation by intracellular calcium chelation. Science 246:257-260.

Sequier JM, Hunziker W, Andressen C, Celio MR (1990) Calbindin D $28 \mathrm{k}$ protein and $\mathrm{mRNA}$ localization in the rat brain. Eur J Neurosci $2: 1118-1126$

Sommer B, Keinänen K, Verdoorn TA, Wisden W, Burnashev N, Herb A, Köhler M, Takagi T, Sakmann B, Seeburg PII (1990) Flip and flop: a cell-specific functional switch in glutamate-operated channels of the CNS. Science 249:1580-1584.

Tang C-M, Dichter M, Morad M (1989) Quisqualate activates a rapidly inactivating high conductance ionic channel in hippocampal neurons. Science 243:1474-1476.

Thayer SA, Miller RJ (1990) Regulation of the intracellular free calcium concentration in single rat dorsal root ganglion neurones in vitro. J Physiol (Lond) 425:85-115.

Tölle TR, Berthele A, Zieglgänsberger W, Seeburg PH, Wisden W (1993) The differential expression of 16 NMDA and non-NMDA receptor subunits in the rat spinal cord and in periaqueductal gray. $J$ Neurosci 13:5009-5028.

Wisden W, Seeburg PH (1993) A complex mosaic of high-affinity kainate receptors in rat brain. J Neurosci 18:3582-3598.

Yamada KA, Tang C-M (1993) Benzothiadiazides inhibit rapid glutamate receptor desensitization and enhance glutamatergic synaptic currents. J Neurosci 13:3904-3915.

Yuzaki M, Mikoshiba K (1992) Pharmacological and immunocytochemical characterization of metabotropic glutamate receptors in cultured Purkinje cells. J Neurosci 12:4253-4263.

Zorumski CF, Thio LL, Clark GD, Clifford DB (1990) Blockade of desensitization augments quisqualate excitotoxicity in hippocampal neurons. Neuron 5:61-66. 